\title{
Um serviço de poesia: o Ofício e as Servidões de Herberto Helder
}

\author{
A poetry service: \\ the Oficio and Servidões, by Herberto Helder
}

Maria Lúcia Dal Farra

Universidade Federal de Sergipe (UFS), Aracaju, Sergipe, Brasil

Resumo: $\mathrm{O}$ ensaio examina, segundo uma perspectiva comparatista, a poesia do poeta português Herberto Helder.

Palavras-chave: Herberto Helder; poesia portuguesa; modernidade

Abstract: This paper examines, from a comparative approach, the poetry of Herberto Helder, a Portuguese poet.

Keywords: Herberto Helder; Portuguese poetry; Modernity

Recebido em 24 de março de 2014. Aprovado em 06 de julho de 2014.

Para a minha querida amiga Linda Santos Costa.

ssumo aqui, como leitora assídua de Herberto Helder,
o meu direito à incompreensão - prerrogativa de que
me invisto no rol das turbulências a que fico exposta diante das inebriantes vertigens dessa obra errática, escorregadia e encantadora. A simultânea legibilidade que oferece, à medida que se expande irrequieta e retorna sobre si mesma em mutáveis remissões, escapulindo à apreensão nesse perpétuo refazimento de um mesmo poema ininterrupto e contínuo - deixa saber que a unicidade de qualquer leitura para aqui não é bem-vinda, já que não pode fazer senão... errar. Texto 
aliciador, medusante e múltiplo, escrito com e contra todos, aterrador na sua sedução hipnótica, refratário à paráfrase e à apropriação linguística alheia - ele desautoriza o comentário crítico e expatria de seus domínios qualquer impulso decodificador. Parece regê-lo uma espécie de conflito de interesses entre o que diz e o leitor, de modo que este ocupa sempre o lugar de um não estar no interior daquele - fato que testemunha, por outro lado, a irremediável solidão dessa obra. ${ }^{1}$

No que lhe concerne, nós, os críticos, somos ditos "abutres [...] entusiastas de cadáveres", "marabundas da interpretação esfaimada", "estrangeiros" à obra, gente tagarela e coscuvilheira, fomentadora tanto do "falatório cultural suplementar" quanto de "outros empreendimentos tribais"... Numa mais recente versão (a que nos chega neste ano, via Servidões), somos também ditos "bárbaros" avançando sobre a Alexandria, prontos a "devastar a terra", a desentranhar do texto "Deus" ou "qualquer espectáculo com cristos nus e saltimbancos de feira". Alçados já agora a prestidigitadores, temos acrescentado à nossa atividade o epíteto de "burrocratas", ao sabor da aversão momentânea da obra pelos contemporâneos (mas para si sempre anacrônicos) sistemas literários e instituições. $^{2}$

Veja-se, no entanto, que, no esforço de apontar para vocês o que nos diz respeito, faço-me presa das teias dessa linguagem. Acabo me acomodando no molde que ela me destina, procedendo da forma como ela me induz. Reparem que estou cedendo à tentação mimética da glosa e que me apego empaticamente ao texto, tomando como confiável o seu parecer a nosso respeito - o que põe em causa a minha competência hermenêutica, já que não guardo, entre mim e ele, a conveniente e objetiva distância crítica. Ao contrário: curvo-me à sua vontade autobibliográfica, que me guia pela soberania autárquica do universo paralelo que cria, e me boto à mercê das leis que, periclitantemente, ele vai formulando ou desmanchando a seu bel prazer.

${ }^{1}$ DIOGO, 1990, p. 61. Lindeza Diogo refere justamente que o leitor parece ser o "nome" que o autor dá ao "não estar" (como completude) na inteireza do texto.

${ }^{2}$ Respectivamente em Nova, em Photomaton \& vox, em Carta de abril e em Servidões. Convencionou-se chamar Carta de abril à carta que Herberto Helder escreve para Eduardo do Prado Coelho, datada de "Cascais, 6 de outubro de 1977", a propósito das alterações, quase individuais, efetuadas pela mão do Poeta sobre os volumes publicados de Cobra - o que o tornava "um livro em suspensão", como bem o definiu e esclareceu Herberto então. A carta foi publicada em 1978 pela $\mathrm{Abril}$, n. 1 . 
Mas tiro disso uma lição. Por mais desavindo que seja, o leitor é, para este texto, sempre a força marginal, parergonal, com que precisa contar para fazer confluir para si (e como seu próprio) qualquer equívoco alheio. Pois a obra de Herberto Helder não se ufana de, errando, nunca deixar de acertar consigo mesma? Esboço, ao menos desse modo, o torturante contraditório que esse texto institui, o regime de caos movediço em que nos submete por mero contato.

Pois foi nessa trilha incerta e derrapante que (temerariamente) defendi em 1979 um trabalho que buscava conhecer as maneiras como até àquela altura essa obra ia ganhando o silêncio que hoje conquistou. ${ }^{3} \mathrm{~A}$ partir do exame de suas catorze primeiras manifestações, naquela altura momentaneamente encerradas por Cobra (exemplo do livro em suspensão em que toda a obra de Herberto Helder se converteria depois), me pareceu que essa escrita brotava, por fim, duma operação alquímica sobre a linguagem, dum processo de depuração e de esvaziamento dos signos que, dissolvendo e coagulando continuamente o poema, conferiam-lhe a feição de algo intérmino e incontestável. Constelação movente de palavras marcadas (sempre na iminência de serem), figurações pirilampas em incessante reajuste, a obra de Herberto Helder não deixava sequer vislumbrar (nessa então derradeira fase do seu processo) o que subjazia ao que se cala e tem sentido, pois que se decantara a ponto de apenas indiciar aquilo que a levava a tal mudez - sempre desarrumando-a de novo e de novo, imparável. Ao longo desse ofício poético, o texto forçara a língua-mãe e cavara nela a sua própria - esculpindo aí o seu território particular, o seu nicho.

Tal travessia se tornara possível porque essa obra acionara aplicadamente o desmanche gradativo tanto da língua quanto da tradição literária. Húmus, O bebedor nocturno, A máquina de emaranhar paisagens encarnavam bem esse olhar diante do passado literário. Da mesma forma, a partir pelo menos de Comunicação acadêmica, Kodak, Cinco canções lacunares e Os brancos arquipélagos, o empenho se dava sobre a desconstrução da gramática, da sintaxe (que subtraía seus laços com a lógica), do vocábulo, e até mesmo do alfabeto, numa ação contestatória

\footnotetext{
${ }^{3}$ Trata-se da minha tese de doutorado defendida na Universidade de São Paulo em setembro de 1979, e publicada em 1986 pela Imprensa Nacional/Casa da Moeda de Lisboa, com o mesmo título: A alquimia da linguagem. Leitura da cosmogonia poética de Herberto Helder.
} 
que não se continha nem mesmo sobre as letras, subvertendo também os sinais gráficos. De modo que, por último, o poema se transformara em linhas, em climas, em partituras, em gás rarefeito, mapas, intensidades, temperaturas, solicitando do leitor tão-só a sua companhia e cumplicidade tácitas: uma espécie de quieta confraternização no mutismo.

Assim se, até àquela altura, o texto de Helder comunicava algo, essa mensagem não passava, ao fim e ao cabo, da produção de alguns vestígios sobre o funcionamento de suas formas de escrita impossível, de sua trégua de vazio, dessa sua maneira específica de ficar quieto - inaugurando uma era de descoberta de um novo mundo verbal (tenho vontade de dizer "atípico Lusíadas em registro mudo"), que não tinha peso e nem nome. ${ }^{4}$

Tal linguagem encantatória, que contava apenas com as propriedades rítmicas, sonoras e melódicas do significante, não se mostrava, entretanto, ungida do luto ou do ofício fúnebre que a morte dos signos poderia porventura lhe emprestar. Ao contrário: exultava de alegria, cumprindo-se como um canto de regozijo próprio das grandes proezas. Afinal, ela coroava a vitória de Orpheu - e a poética de Helder reencontrava, por essa via, o mítico, exatamente no limiar da utopia que estivera todo tempo engendrando para si.

$\mathrm{O}$ retorcimento da linguagem (e, consequentemente, do real que, intermitente, vai se apagando esmagado por esse mundo virtual), a prática de tais crimes de lesa-escritura - cunhavam então, com o selo da "crueldade", essa contraescrita já muito próxima do "idioma demoníaco" que Helder praticaria a partir das décadas seguintes. ${ }^{5}$ Por sua vez, o

\footnotetext{
${ }^{4}$ Estou me referindo ao trabalho gradativo sobre a linguagem que o montante inicial da obra poética de Herberto Helder até, pelo menos, 1977, vinha elaborando desde $O$ amor em visita (1958): A colher na boca (1961), Poemacto (1961), Lugar (1962), A máquina de emaranhar paisagens (1964), Comunicação académica (1965), Retrato em movimento (1967), Húmus (1967), O bebedor nocturno (1968), Kodak (1968), Cinco canções lacunares (1969), Os brancos arquipélagos (1970), Antropofagias (1971) até Cobra (1977). ${ }^{5}$ Sigo, aqui, a acepção do "demoníaco" em Goethe, visto enquanto "energia positiva" em "absoluta superioridade de potência". O "demoníaco" se distingue "da negatividade do diabólico e o concebe como qualquer coisa que não se manifestava senão através de contradições e que não se podia, por conseqüência, traduzir, nem mais ou menos em palavra" (GOETHE apud LOPES, 2003, p. 26). Acompanho também o conceito a partir da visão que Kierkegaard lhe confere, visto que aqui se liga ao mutismo, à perda da palavra, ao silêncio, à reticência, à sujeição voluntária, à afasia, à falta de continuidade (muito embora aparentando o contrário), à aparição do "súbito" como corte da mesmice contínua
} 
Autor já há tempos desaparecera (como diz Fiama) "nos precipícios que são os textos", tendo morrido "imensamente a(ssa)ssinado", ele próprio um assíduo "assassino assimétrico" ou não da sua perene leitura de Camões, ${ }^{7}$ de Rimbaud, Artaud, Jarry, Nietzsche, por exemplo, e apadrinhado por um certo romantismo alemão via Hölderlin. A lógica aristotélica, o racionalismo cartesiano, ficavam agora obnubilados por um diapasão de teor paleológico, que introduzia definitivamente nessa obra o descentramento e a catástrofe. E a poesia de Herberto Helder ingressava, pois, na sua decisiva "radicalização lírica", abolindo a verossimilhança, o espelho refletor, o mimetismo, os mecanismos argumentativos, a dialética, como também os traços típicos do discurso: a ordenação temporal e espacial, a lógica sintática. Ela se guia então pela contradição, pelos tropeços inesperados e súbitos, pela simultaneidade de respostas, pela produção do múltiplo, pela concomitância de opostos - que, aliás, jamais se socorrem da síntese dialética. Move-se no campo do acaso e das metamorfoses arbitrárias, em pleno regime "demoníaco" - daquilo que é da ordem do excesso e do entusiasmo, do ultrapassamento do que limita ou interdita, recolocando, através do vazio e dos rearranjos sobre ele, tanto o pathos do terror quanto um novo sublime, recolhido no inaproximável, no inacessível, no impensável, no indizível. Entre o mistério tremendo e o mistério fascinante, ela se deleita com o impossível. Porque o poema, dúbio, propositadamente afásico e claudicante, não se pronuncia sobre nada e, na língua que usa (e que desnaturaliza a língua-mãe testando suas fronteiras, abalando os alicerces dela e ocupando seus baldios) - ninguém ainda fala.

De maneira que ele despreza qualquer rentabilidade cultural e sequer procura algum tipo de salvação. Aliás, tais horizontes nem the são colocados, uma vez que a categoria sacrificial está extinta, e que os valores e as hierarquias que antes porventura o norteavam não mais vigoram nessa nova constelação. O texto de Helder quer tão-só expor

- como o trata Chrétien (1989). Segundo Sophie Houdard, o "demoníaco" comanda, desse modo, "todos os caminhos do equívoco, da dúvida e do erro" (HOUDARD, 1992, p. 222). ${ }^{6}$ Verso citado do poema de BRANDÃO, 1974. Em seguida, citação do poema de HELDER, 1973, p. 206. Em seguida, menção ao poema de HELDER, 1973, p. 149, onde se encontra formulado como "talento assimétrico de assassino". Este texto integrara anteriormente "As festas do crime", de Vocação animal (1971), às p. 69- 71, e, antes ainda, "As palavras", de Apresentação do rosto (1968), às p. 190-191.

${ }^{7}$ Ver o meu "Herberto Helder leitor de Camões" (DAL FARRA, 1978, p. 67-90). 
o seu próprio desequilíbrio: confrontar-se com o vazio, com o terror, mesmo sabendo que deles não pode escapar. Busca ser apenas um lugar de linguagem, de ressonância, um espaço verbal onde o mundo acaba, renasce e acaba de novo; onde a morte e a vida e a morte ocorrem sem nunca cessar. Nada empreende demonstrar, nem conhecer, nem provar: quer apenas interrogar o silêncio, fazer-se sede de agenciamentos e de metamorfoses - garantir sua existência coruscante.

Nem relativa nem absoluta, a língua em que fala-não-falando é alterante, performática. E o texto anda à deriva, guiado por mão canhestra, ao sabor de deslocações, permutas, modulações, analogias, desdobramentos relacionais e seriais, num rigoroso turbilhonamento sem síntese, sem fim. Nele, as palavras são só corredores circulatórios disponíveis para outra e outra palavra, enquanto a figuralidade é um coletivo imagético que permite, numa escala mais ampliada, tal expansão interminável, contínua, abrindo-se numa ventilação sígnica por todos os cômodos e interstícios do poema. Esse é o seu diafragma, a sua respiração - sua ameaçada e relampejante existência.

Situei aqui essa pequena síntese sobre a obra de Herberto Helder ${ }^{8}$ para poder introduzir, neste contexto, algumas cogitações acerca da sua mais recente produção - o volume Servidões, editado em maio deste ano de $2013 .{ }^{9}$

Pra já, o fato de ter vindo à luz com a indicação expressa de "única publicação" toma vários contornos. Tal decisão é semelhante, nesse aspecto, à da obra imediatamente anterior, A faca não corta o fogo, que, depois de publicada uma única vez, em setembro de 2008, e imediatamente esgotada, passa a integrar em 2009 (e provisoriamente, aliás, como todos os volumes da obra helderiana) o Oficio cantante. Poesia completa. Ou seja: a reescrita ou a revisita dos poemas de Herberto Helder por ele mesmo. ${ }^{10}$

Como já mencionei, a obra de Herberto se aplica em apagar de si os traços de seu Autor: seja por meio da figuração que lhe oferece, seja através da dramatização de outras autorias nela exibidas. Aliás, para uma língua que não quer falar, não há sujeito (muito menos com nome

${ }^{8}$ Tenho me referido, nessa rápida síntese, ao montante da obra poética de Helder posterior a 1979: Photomaton \& vox (1979), Flash (1980), A cabeça entre as mãos (1982), As magias (1987), Última ciência (1988), Os selos (1990), Os selos, outros, últimos (1990), Do mundo (1994), A faca não corta o fogo (2008), obras que fazem parte da edição de Ofício cantante. poesia completa (janeiro de 2009).

${ }^{9}$ HELDER, 2013.

${ }^{10}$ HELDER, 2009. 
ou figura civil) que ela possa admitir como enunciador desse discurso situado em grau nulo. Da mesma forma, e fiel a seu ofício, o cidadão Herberto Helder vive (em sintonia com o que produz) ausente da cena pública literária, recusando (como é notório) prêmios e louvores. Em suas raríssimas aparições, nunca de cunho pessoal mas sempre de lavra escrita - como na Carta de abril, por exemplo, ou nas infrequentes entrevistas - é sempre a obra que fala nele, dissolvida a biografia, que nunca é para ali chamada. Aliás, os únicos traços que dela vigoram se assentam em sua escrita como insolventes, ${ }^{11}$ nela enraizados só enquanto formulação gramatical. Nesse sentido, é provável que os pareceres críticos que constataram em Apresentação do rosto uma "autobiografia" tivessem contribuído para a recusa desse livro no rol das obras do Autor. ${ }^{12}$

De resto, o perene apagamento autoral implicita, da parte de Herberto, não só uma fuga às estratégias do marketing mas também outras recusas: a de auxiliar a venda do seu produto, a de se deixar manipular como autoridade diante da sua obra. Por isso mesmo, a decisão declarada de uma "única edição" desse derradeiro livro aparecia aos olhos da crítica atenta como uma heroica façanha contemporânea de reposição, sobre a sua poesia, da aura perdida. Esforço baldado, no entanto. Esforço frustrado pateticamente pelo cinismo da indústria editorial diante da obra, visto que, com exímia rapidez, ela se apropria do livro, capturando-o como objeto de posse, fazendo triunfar nele o seu valor de troca, de cota mercadológica. De maneira que essa desafiante edição se esgota quase de imediato, consumida não só por leitores, mas pela pura especulação comercial em torno da sua unicidade. E o mercado cultural sai vencedor, mostrando aí, mais uma vez, a sua face mais perversa. ${ }^{13}$

Diante disso, julgo lícito perguntar se, dentre as "servidões" sugeridas pelo título desse derradeiro livro, não estaria também prevista essa. Quero dizer: há, certamente embutida nesse livro, uma acepção concernente a um serviço perene à poesia. Há também uma outra: a

\footnotetext{
${ }^{11}$ Helder refere "insolvência biográfica", na apresentação em prosa de Servidões, à p. 12. ${ }^{12}$ João Palma-Ferreira, em "Os Passos em Volta" (1970, p. 92-93), refere Apresentação do rosto como uma "autobiografia romanceada", como "uma das mais corajosas e terríveis confissões autobiográficas da literatura portuguesa". Não só Palma-Ferreira, mas outros pares também demonstraram igual opinião.

${ }^{13}$ Antonio Guerreiro, em "Herberto Helder poeta da aura" (2013, p. 10), reflete sobre essa questão em termos semelhantes.
} 
servidão camoniana da "tão curta vida", a da vassalagem à Dona, na tradição medieval, que é, aliás, um serviço de amor - amor, palavra cuja emblemática se ostenta como a mais expansiva da poética de Herberto. E há também a servidão "lenta" aos "episódios dessa guerra", da qual também se morre, como atenta Servidões à p. $12 .{ }^{14}$

Ora, o cativeiro a que nos submete o mercado cultural (e sem o qual nenhum livro entra em circulação de leitura) - não estaria, por antecipação, incrustado no vaticínio camoniano (aqui também implícito) "de servir a quem vence, o vencedor"? ${ }^{15}$ Não teria o nosso Autor topado direta e duramente com esse "Senhor", aquando da edição de A faca não corta o fogo? E não estaria ele agora, nesta última publicação, alertandonos (desde o título) para essa insana e inescapável "servidão"?

Notem que a epígrafe do livro parece insinuar (tácita e decassilabicamente) essa desconcertante constatação acerca do mundo:

dos trabalhos do mundo corrompida que servidões carrega a minha vida?!

O fato é que Servidões revisita textos próprios, reapropria-se deles, dialoga com eles e também com uma série de outras referências alheias, citadas ou sugeridas. Procede assim com Edoi lelia doura, com Cobra, com A máquina de emaranhar paisagens, com Apresentação do rosto, com Photomaton \& vox, por exemplo. Também com Camões, Dante, Villon, Verlaine, Cesare Pavese, Rimbaud, Goethe, Von Kleist, Cavafi, Issa, etc. E, nesse diapasão, um dos poemas chega mesmo a indicar "uma bibliografia dispensável" que envolve a obra de Anthony Grafton, numa específica tradução: a de Antoine Fabre - Les origines tragiques de l'érudition. Une histoire de la note en bas de page. O que puxa a atenção do leitor, de novo, para o limiar da poética de Helder, para aquela zona dúbia onde se deposita o parergon, ou seja, para aquilo que, estando no limite exterior, se encontra permanentemente em falta no interior. ${ }^{16} \mathrm{E}$, segundo creio, esse desenho, que desloca as hierarquias, não diz apenas respeito ao descentramento dos poemas, mas também ao da própria obra. Segundo se lê na introdução em prosa de Servidões, é numa

\footnotetext{
${ }^{14}$ Doravante, quando citar Servidões, indico apenas as páginas respectivas entre parênteses.

${ }^{15}$ Refiro-me aqui a dois sonetos camonianos: primeiro, a "Sete anos de pastor Jacob servia"; e, agora, a "Amor é fogo que arde sem se ver".

${ }^{16}$ Ver DERRIDA, 1972.
} 
"espécie de nota que se capta a razão inteira, no centro" e que todo "o livro vai sendo o seu prefácio, e o posfácio, a inacessível e prontamente acessível evidência" (p. 15). É provável que suas razões estejam, pois, nesse entre-estar, na prega, no enxerto, no seu cólofon.

E os temas obsediantes da obra de Helder reaparecem também aqui: a cabeça, o espelho, o amor, a mulher, o sangue, a morte, o leitor, as cenas da escrita, bem como as marcadas palavras "ar" e "fogo". Talvez estas últimas insinuem, na fluidez e na combustão instantânea que atiçam, o sentido de urgência que atravessa esse livro, a sublinhada carência de tempo que, por vezes, esboça uma poética do pouco, da carência, da economia, do espaço apertado, da míngua - da "tão curta vida" camoniana.

Escritos "com sangue na esferográfica" (p. 38), esses textos, que se querem ora curtos ora longos, perfazem um livro de limiar, do agora, do aqui, do tempo presente, expresso com uma intenção testamentária de "morte no gerúndio" (p. 96), de fim iminente, onde a "dor" comparece vigiada (ou administrada?) pela ironia e pelo humor negro. O que ajuda a supor que estamos diante de uma obra escatológica - tanto de fim dos tempos quanto na sua versão de emprego do obsceno e da autoexecração.

Leio um poema capaz de resvalar o que digo, em que há um bizarro e mordaz ritual (talvez de purificação), uma liturgia mista composta de extrema-unção, epitáfio, cremação e batismo, permeada pelo fogo e também pelas águas: pelas imundas águas do esgoto que se misturam com as sagradas e primordiais águas bíblicas:

cheirava mal, a morto, até me purificarem pelo fogo:

e alguém pegou nas cinzas e deitou-as na retrete e puxou o autoclismo, resquiescat in pace,

e eu não descanso em paz nas retretes eternas,

a água puxaram-na talvez para inspirar o epitáfio,

como quem diz:

aqui vai mais um poeta antigo, já defunto, é certo, mas em vernáculo e tudo, que

Deus o receba como ambrosia sutilíssima nas profundas dos esgotos

merda perpétua,

e fique enfim liberto do peso e agrura do seu nome:

vita nuova para este rouxinol dos desvãos do mundo,

passarão a quem aos poucos foi falhando o sopro

até a noite desfazer o canto,

errático canto e errado no coração da garganta, canto que o traspassava pela metade das músicas

- e ao toque no autoclismo ascendia a golfada de merda enquanto as turvas 
águas últimas

se misturavam com as águas primeiras (p. 104-105)

O autor aqui dramatizado não se poupa, revisitando-se amargamente como "sobrevivente ao desastre das artes" (p. 60, 71), num olhar angustiante sobre si mesmo (matizado de azedume), embora trabalhe, assiduamente, um "esperançoso esperanto" (p. 42) em "língua inexpugnável" (p. 32), em "verbo arcaico indefectível cerrado" (p. 34). Mas isso não evita o movimento mais perceptível do livro, que é o de uma catábase, de descida aos Infernos, que marca o seu feitio de une saison en enfer pendendo já agora para o silêncio de Harrar. É mesmo como se, no dizer de Manuel Gusmão, Helder ousasse se despedir da língua: ${ }^{17}$ ou como se nela tecesse para si um ninho, um refúgio, trabalhando ali um lugar em que se possa morrer. Que se possa morrer ou nascer, morrer e nascer: não esquecer que o cordão umbilical, tão emblemático dessa poética, é também aqui (oh Villon!) o "cordão de sangue à volta do pescoço" (p. 20), o que torna o poeta definitivamente disposto, "iminente" - tanto para o nascimento quanto para a morte. ${ }^{18}$

Para além dos textos em prosa que abrem o volume, comparecem, em Servidões, 73 poemas que se seguem um no outro, no rumo do interminável e do incontestável (atributos helderianos já anotados), e que também incluem aquela consabida sabotagem no interior da língua. Misturam francês, inglês, italiano, alemão, brasileirismos; fazem passagens abruptas de contextos discursivos e linguísticos alterando a hierarquia da fala; empregam graficamente o código espanhol para a interrogação; usam acentos diferenciais para os vocábulos, como se inventassem para uso particular um acordo-ortográfico-do-eu-próprio.

Há, na interlocução interna desse livro, um enlace maior com Apresentação do rosto. Lá, celebravam-se os 8 anos; aqui, celebram-se os 80. Lá, a ilha que mais tarde conheceríamos como aquela "em forma de

\footnotetext{
${ }^{17} \mathrm{~A}$ frase toda de Manuel Gusmão, citada por Luís Miguel Queirós em "Herberto Helder. A arte de ser único" (2013, [s.p.]) é: "É como se Herberto Helder tivesse a audácia de se despedir de uma língua como quem se despede de uma vida, num momento em que estamos sob ocupação política".

${ }^{18}$ Gastão Cruz refere, em Última ciência, a "cristalização do cordão umbilical" em "Leva um braço às costas" (CRUZ, 2008, p. 251). Além disso, refiro-me à "Balada dos enforcados" de Villon.
} 
cão sentado" de Photomaton \& vox ${ }^{19}$ (e que aqui, neste contexto, parece ser já a de Cérbero) - reaparece num retorno em que tudo é outra coisa não reconhecível - mas onde, por fim, se identifica "a vida subtil, unida e invisível [...] compacta e limpa. Gramatical" (p. 18). A mulher, a mãe, o inexorável, o não haver e haver remissão, a sobrevida, a inutilidade de tudo, a representação do mundo como figura (como "tinta" camoniana), o presente, o futuro, o morrer e o desmorrer, o balanço da vida, as determinações testamentárias, a vida a partir do próprio esquecimento, o lavrar um livro - são motivos muito palpitantes nessa obra.

E faz espécie, em Servidões, o aparecimento de uma nova dramatização de persona. Segundo se constata no poema que acabei de ler, Helder parece ter criado aqui, para enfrentar tais questões da autoironia, da autodepreciação, da aridez interior, da angústia, da paralisia da ação uma voz que lembra, em muito, a de um ácido Álvaro de Campos, o da última fase, aquele para quem "a única conclusão é morrer". ${ }^{20}$ Claro que se trata (para dizer o óbvio!) de uma versão absolutamente helderiana e pósmoderna do heterônimo pessoano, composta num diapasão específico, ao sabor de entrecortes, de saltos de registros, cunhada pelo idioma demoníaco de Helder - mas cuja ressonância lembra muito a dicção e até uma certa prosódia de Campos. É como se Helder tivesse encontrado, num disponível Campos, um outronímico de reserva que, reatualizado na sua contemporaneidade e contingenciado com suas próprias feições, pudesse cumprir agora a impossível missão de se defrontar sarcástica (e comovidamente!) com a morte aos 80 anos.

No poema que leio, esse Campos helderiano procede como se invocasse as musas de Camões, cuja fórmula linguística já comparecera, aliás, em $O$ amor em visita. Mas se nesse livro inaugural invocavam a mulher ("Dai-me uma jovem mulher com sua harpa de sombra"), no poema desse derradeiro livro invoca-se, por meio dela, o êxtase infernal e, como em Os Lusíadas, não bem a inspiração, mas a "força" infernal e o "ofício" dos idiomas na sua própria glória. Porque se faz aqui, num

${ }^{19}$ Trata-se do texto "(Uma ilha em sketches)" (HELDER, 1979, p. 15-25).

${ }^{20} \mathrm{O}$ verso pertence a "Lisbon revisited", de 1923. Só para ficarmos à roda do Orpheu, lembro que, em Última ciência, Gastão Cruz repara que a essência barroca daquela poesia de então remetia à poética de Mário de Sá-Carneiro, no seu "tão ostensivo culto da sumptuosidade das imagens: flores, animais, pedras preciosas, tecidos, astros, percorrem esta poesia numa apoteose ininterrupta de brilhos e de prodígios" (CRUZ, 2008, p. 252). 
flash, a revisita e a atualização (para a pós-modernidade) da Divina Comédia, poupando o leitor dos seus "tantos capítulos", e situando num outro registro, poético e maldito, as estanques divisões do post mortem:

pensam: é melhor ter o inferno a não ter coisa nenhuma

- como a tantos tanto o nada os apavora!

eu acho que o gênio da doutrina está nessa promessa exímia:

ninguém que espere a eternidade

espera o paraíso:

provavelmente o paraíso é improvável como imagem, dêem-nos

algum pouco do inferno, o bastante para

ocupações gerais,

trabalhos breves,

jogos da mente,

jogos distraídos,

jogos eróticos talvez, os muçulmanos tiveram palpite disso,

e os cristãos que receberam formação comercial, penso:

ia pôr a mão no fogo, ia cortar uma orelha,

eu que em mim sou obscuro, não, não,

então recebe lá a minha prece quotidiana:

dá-me o êxtase infernal de Santa Teresa De Ávila

arrebatada ar acima num orgasmo anarquista,

a idéia de paraíso é apenas um apoio

para o salto soberano,

não um inferninho brasileiro com menininhas de programa,

púberes putinhas das favelas,

mas o inferno completo onde passeia a Beatriz das drogas duras,

um inferno à medida de cada qual dificílimo,

onde se é evasivo,

subtilezas desde o xadrez à física quântica,

à poesia pura,

aos fundamentos da levitação xamânica,

ao sufismo,

ao surfismo

¿a metáfora do fogo, de que argúcias e astúcias é ela rarefeita?

¿e a metáfora da água?

a idéia de paraíso é muito brutal e louca,

e o purgatório como purga é tão torpe, tão terrestre, tão trivial e trôpego,

tão político,

tão tenebroso!

não resulta, 
dá-me esse inferno oh quanta força e ofício nos idiomas:

formar uma estrutura estritamente poética

na sua glória mesma, só com uma inteligência de duplos sentidos, o poema que pede mais que dez dedos, nem os braços lhe bastam e o coração ao meio, e os cinco litros de sangue com que se abraça tudo e se abusa do mundo, e o político e o cívico e o administrativo e o econômico-financeiro, enfim o ínvio, para que tantos capítulos? oh claros corredores ao longo das vozes a capella, sim sim, organizam a morte, e depois quem tem sorte entra pelo inferno dentro, fulgurante, poemático, edições os trabalhos do diabo, post-scriptum: meu amor, o inferno é o teu corpo foda a foda alcançado, e lá fora eles cantando, os castrati, a capella, vozes furiosamente frias, limpas, devastadoras, oh maldita cocaína, musa minha, droga pura, minha aranha idiomática, estrela de cinco pontas, o fundo do ar ardendo, e os já ditos braços meus muito abertos, e entre os braços o já dito coração aos pedaços always toujours sempre oh pulsando pulsando! (p. 97-100)

Os poemas que convivem com o fantasma de Campos, os das edições, "os trabalhos do diabo", são menos curtos. Se pudéssemos reunilos, quem sabe poderiam compor uma grande ode à saturação diante dos desmandos do mundo, numa escrita que nunca falece porque atravessa seus infernos próprios e seus íntimos demônios, deles se alimentando. Tais poemas adotam, por vezes, uma fala cotidiana, transportada, de súbito, para outros patamares que lhes transmutam por completo a natureza. Há o uso, por vezes, de uma escrita desfavorecida que se embrenha neles e os assalta, de repente, dessacralizando quaisquer laivos formais; por vezes surgem estilhaços de odes, um tanto grandiloquentes, que se esfumam entremeados por uma baixa expressão ridicularizante; por 
vezes deparamo-nos com fakes de odes, que fazem o elogio ao contrário e cantam o desprazer e o aborrecimento, derivando para o calão. Se, porventura, se eleva súbito o tom do poema é para que se contraste com uma sórdida sublimidade oriunda do baixo mundo, capaz de introduzir o insulto ${ }^{21}$. Tudo isso convive ao mesmo tempo nessa escrita. O que dá a impressão de que, em algum momento desses poemas, brota de chofre uma flor monstruosa e aterradora - talvez a Welwitschia mirabilis do poema 48 - benéfica apenas aos escorpiões do deserto. ${ }^{22}$

Assim, num texto, o poeta almeja ficar amarrado dentro de um "saco sem qualquer salvação nos armazéns obscuros" (p. 36). Noutro, ele está "mal, obrigado - e o sangue corre e escorre dentro e fora" (p. 33). Noutro, "tudo acaba: canção, talento, alento, papel, esferográfica" (p. 42); noutro, "esta cabeça não é minha, dizia o amigo, que me disse,/ esta morte não me pertence" (p. 56); noutro, ele segue "rumo ao inferno que já em vida conhecera" (p. 61); noutro, conclui-se que o mundo é "pequeno,/ mais pequeno com certeza que um poema de um verso único,/ universo"; noutro, ele morrerá do seu "muito terror e da nenhuma salvação da" sua vida (p. 81); noutro, pede que deixem passar o cadáver pois que "a portagem foi já paga" (p. 89); noutro, exige que não nos esqueçamos apenas dele, mas de toda a sua geração, da "geração inteira/inclitamente vergonhosa,/ que em testamento vos deixou esta montanha de merda", essa "merda eminentíssima" (p. 91); noutro, "nada tem retorno e tudo é dificílimo/(não só o máximo mas também o mínimo)" - e daí por diante.

Há ainda muito, muito ainda para pensar e escrever sobre esse livro, compreendendo-o ou não. Mas, por ora, me despeço dele e de vocês com este poema 65 , que nos reenvia para um tanto do que tenho mencionado:

daqui a uns tempos acho que vou arvoar

através dos temas ar e fogo,

a mim já me foram contando umas histórias que me deixaram meio louco furioso:

${ }^{21}$ Os poemas mais marcados por essa presença seriam os de número 11, 12, 13, 16, 17, $29,32,46,47,49,50,56,57,62,63,64,65,68,71$, por exemplo.

${ }^{22}$ A Tumboa ou Welwitshia mirabibilis, nativa do deserto de Nanibe, remete à Angola. Sua longevidade atinge mais de mil anos; é unissexual; abre-se à noite respirando o orvalho e o carbono que a alimentam, e fecha-se durante o dia. Transforma, assim, o carbono (que asfixia) e a aridez (inóspita) em vida longeva; suas folhas atingem mais de dois metros. 
um bando de bêbados entrou num velório e pôs-se à bofetada no morto, e riram-se todos muitíssimo, que lavre então a loucura, disse eu, e toda a gente se ria, até a família, tudo tão contra a criatura ali parada em tudo, equânime, nenhuma, contudo, bem, talvez, quem sabe?

talvez se lhe devesse a honra de uma pergunta imóvel, uma nova inclinação de cabeça

- à bofetada! -

fiquei passado mas, pensando durante duas insônias seguidas,

pedi:

metam-me, mal comece a arvoar, directo, roupas e tudo, no fogo

e quem sabe?

talvez assim as mãos violentas se não atrevam por causa da abrasadura, porém enquanto vim por aqui linhas abaixo:

ora, estou-me nas tintas:

pior que apanhar bofetadas depois de morto é apanhá-las vivo ainda, e se me entram portas adentro!

¿Eli, Eli?

um tipo de oitentas está fodido, morto ou vivo, e os truques: não batam mais no velhinho, olhem que eu chamo a polícia, etc. - já não faíscam nas abóbodas do mundo: vou comprar uma pistola, ou mato-os a eles ou mato-me a mim mesmo, para resgatar uns poemas que tenho ali na gaveta, nunca pensei viver tanto, e sempre e tanto no meio de medos e pesadelos e poemas inacabados, e sem ter lido todos os livros que, de intuição, teria lido e relido,e treslido num alumbramento, e é pior que bofetadas, vivo ou morto, pior que o mundo, e o pior de tudo é mesmo não ter escrito o poema soberbo acerca do fim da inocência, da aguda urgência do mal:

em todos os sítios de todos os dias pela idade fora como uma ferida, arvoar para o nada de nada se faz favor, e muito, e o mais depressa impossível, e com menos anos, mais nu, mais lavado de biografia e de estudos da puta que os pariu (p. 106-108) 


\section{Referências}

BARRENTO, João. Fulgor e ritmo: tradução e escrita em Maria Gabriela Llansol e Herberto Helder. O arco da palavra. Ensaios. São Paulo: Escrituras, 2006. p. 175-183.

BASTOS, Jorge Henrique. A gramática cruel de Herberto Helder. In: HELDER, Herberto. O corpo o luxo a obra. São Paulo: Iluminuras, 2009. p. 9-12.

CARVALHO, Gil de. HH. 'Ouolof', 'Poemas ameríndios', 'Doze nós numa corda'. Colóquio/Letras, Lisboa, n. 155-156, p. 425-417, jan. 2000.

CARVALHO, Gil de. Herbertiana. Colóquio/Letras, Lisboa, n. 125-126, p. 231-233, 1992.

CATTANEO, Carlo Vittorio. Introduzione. In: HELDER, Herberto. Vocazione animale. Introdução e tradução de C.V. Cattaneo. Siena: Quaderni di Messapo, 1982. p. 5-15.

CHRÉTIEN, Jean-Louis. Perdre la parole. In: RAYMOND, Didier. Kierkegaard, ou, Le Don Juan chrétien. Monaco: Éditions du Rocher, 1989. (Les Cahiers du Rocher). p. 161-173.

COELHO, Alexandra Lucas. Comer Herberto. Público, Lisboa, 10 out. 2008. Ípsilon, p. 5-8.

COELHO, Eduardo Prado. Chega a mão a escrever negro. Público, Lisboa, 03 nov. 2006. Ípsilon, p. 21.

COELHO, Eduardo Prado. Meios de transporte. Amor e morte na poesia portuguesa contemporânea. Colóquio/Letras, Lisboa, n. 92, p. 42-48, jul. 1986.

CRUZ, Gastão. Herberto Helder: Como se ele mesmo fosse o poema. In: . A vida da poesia. Lisboa: Assírio \& Alvim, 2008. p. 254-255.

CRUZ, Gastão. Herberto Helder: Os passos em volta ou "O caminho para o conhecimento". In: . A vida da poesia. Lisboa: Assírio \& Alvim, 2008. p. 243-248.

CRUZ, Gastão. O mito materno na poesia de Herberto Helder - Última ciência. In: . A vida da poesia. Lisboa: Assírio \& Alvim, 2008. p. 249.

CRUZ, Gastão. Última Ciência ou “A arte plenilúnia das palavras". In: . A vida da poesia. Lisboa: Assírio \& Alvim, 2008. p. 250-253.

DAL FARRA, Maria Lúcia. Herberto Helder leitor de Camões. Revista Camoniana, São Paulo, série 2, v. 1, p. 67-90, 1978. 
DAL FARRA, Maria Lúcia. Herberto Helder: a ars poética do assassino assimétrico. Estudos Portugueses e Africanos, Campinas, n. 1, p. 79-94, 1983.

DAL FARRA, Maria Lúcia. Herberto Helder: A cabeça entre as mãos. Leia Livros, São Paulo, n. 66, p. 17, 1984.

DAL FARRA, Maria Lúcia. Para o leitor ler de/vagar Herberto Helder. Letras, Curitiba, n. 24, p. 219-227, 1975.

DAL FARRA, Maria Lúcia. Posfacial. In: HELDER, Herberto. O corpo o luxo a obra. São Paulo: Iluminuras, 2009. p. 149-157.

DAL FARRA, Maria Lúcia. The Feminine in the Poetry of Herberto Helder, de Juliet Perkins. Colóquio/Letras, Lisboa, n. 125-126, p. 316317, jul. 1992.

DAL FARRA, Maria Lúcia. A alquimia da linguagem. Leitura da cosmogonia poética de Herberto Helder. Lisboa: Imprensa Nacional / Casa da Moeda, 1986.

DERRIDA, Jacques. La dissémination. Paris: Seuil, 1972.

DIOGO, Américo António Lindeza. Herberto Helder: texto, metáfora, metáfora do texto. Coimbra: Almedina, 1990.

DUARTE, João Ferreira. Poemas mudados para o português. Textos Pretextos, Lisboa, n. 17: Herberto Helder, p. 56-58, outono-inverno 2012.

EIRAS, Pedro. A pedra na cabeça. HH, René Descartes, uma questão de loucura. Textos Pretextos, Lisboa, n. 17: Herberto Helder, p. 20-33, outono-inverno 2012.

FREITAS, Manuel de. Uma espécie de crime: Apresentação do rosto de HH. Lisboa: \&etc, 2001.

FURTADO, Maria Teresa Dias. A dialética do silêncio em HH. Colóquio/ Letras, Lisboa, n. 35, p. 73-76, jan. 1977.

GOETHE, Johann Wolfgang von apud LOPES, Silvina Rodrigues. $A$ inocência do devir. Ensaio a partir da obra de Herberto Helder. Lisboa: Edições Vendaval, 2003.

GUERREIRO, António. A poesia, batismo atônito. Textos Pretextos, Lisboa, n. 17: Herberto Helder, p. 52-55, outono-inverno 2012.

GUERREIRO, Antonio. Herberto Helder, poeta da aura. Público, Lisboa, 14 jun. 2013. Ípsilon, p. 10. 
GUERREIRO, Antonio. Poesia e terror. Público, Lisboa, 14 jun. 2013. Ípsilon, p. 33.

GUERREIRO, António. Teoria das catástrofes. Expresso, Lisboa, p. 34, 14 fev. 2009.

GUIMARÃES, Fernando. Acerca da publicação de 'Poesia Toda' de Herberto. Colóquio/Letras, Lisboa, n. 15, p. 70-73, set. 1973.

GUIMARÃES, Fernando. HH: de uma possível análise crítica de sua obra a uma antologia polêmica. Colóquio/Letras, Lisboa, n. 86, p. 66-69, jul. 1985.

GUIMARÃES, Fernando. Revisão da moderna poesia portuguesa. Colóquio/Letras, Lisboa, n. 1, p. 34-44, mar. 1971.

GUSMÃO, Manuel. Carlos de Oliveira e Herberto Helder: ao encontro do encontro. In: . Tatuagem \& Palimpsesto. Da poesia em alguns poetas e poemas. Lisboa: Assírio \& Alvim, 2010. p. 339-361.

GUSMÃO, Manuel. HH2. Textos Pretextos, Lisboa, n. 17: Herberto Helder, p. 15-16, outono-inverno 2012.

GUSMÃO, Manuel. Leiam Herberto Helder Ou o poema contínuo. Tatuagem \& Palimpsesto. Da poesia em alguns poetas e poemas. Opus Cit. p. 362-366.

GUSMÃO, Manuel. Herberto Helder, a estrela plenária. In:

Tatuagem \& Palimpsesto. Da poesia em alguns poetas e poemas. Lisboa: Assírio \& Alvim, 2010. p. 367-387.

HOUDARD, Sophie. Les sciences du diable. Quatre discours sur la sorcellerie. Paris: Cervf, 1992.

LOPES, Silvina Rodrigues. Versões de HH. 'As magias'. Colóquio/ Letras, Lisboa, n. 102, p. 115-116, mar. 1988.

LOPES, Silvina Rodrigues. A inocência do devir. Ensaio a partir da obra de Herberto Helder. Lisboa: Vendaval, 2003.

LOPES, Silvina Rodrigues. DAL FARRA, Maria Lúcia. Alquimia da linguagem. Colóquio/Letras, Lisboa, n. 99, p. 125-127, set. 1987.

LOPES, Silvina Rodrigues. Provas sem prova. Textos Pretextos, Lisboa, n. 17: Herberto Helder, p. 78-80, outono-inverno 2012.

MARTELO, Rosa Maria. A matéria das imagens. Textos Pretextos, Lisboa, n. 17: Herberto Helder, p. 74-77, outono-inverno 2012. 
MARTELO, Rosa Maria. Assassinato e assinatura. A forma informe. Leituras de poesia. Lisboa: Assírio \& Alvim, 2010. p. 83-111.

MARTELO, Rosa Maria. Um lance último. Público, Lisboa, 14 jun. 2013. Ípsilon, p. 9.

MARTINHO, Fernando J. B. HH, 'Poesia toda 2'. Plátano, 1973. Colóquio/Letras, Lisboa, n. 25, p. 79-81, maio 1975.

MARTINHO, Fernando J. B. HH - 'Cobra' - 1977. Colóquio/Letras, Lisboa, n. 44, p. 77-79, 1978.

MIRANDA, Rita Novas. Uma escrita para ver. Textos Pretextos, Lisboa, n. 17: Herberto Helder, p. 34-49, outono-inverno 2012.

MORÃO, Paula. HH - 'Última ciência'. Colóquio/Letras, Lisboa, n. 113-114, p. 210-211, jan. 1990.

PALMA-FERREIRA, João. 'Os passos em volta', de Herberto Helder. Colóquio/Letras, Lisboa, n. 4, p. 92-93, dez. 1971.

PERKINS, Juliet. As filhas do tempo. Análise de um poema de HH. Colóquio/Letras, Lisboa, n. 65, p. 14-22, jan. 1982.

PIMENTEL, Diana. Herberto Helder. 'Do mundo'. Colóquio/Letras, Lisboa, n. 140-141, p. 198-201, abr. 1996.

PIMENTEL, Diana. 'Ofício cantante', de Herberto Helder. Colóquio/ Letras, Lisboa, n. 173, p. 198-201, jan. 2010.

QUEIRÓS, Luís Miguel. Herberto Helder. A arte de ser único. Público, Lisboa, 14 jun. 2013. Disponível em: <http:/www.publico.pt/temas/ jornal/herberto-helder-a-arte-de-ser-unico-26642124>. Acesso em: 15 dez. 2014.

QUEIRÓS, Luís Miguel. Por que te calas? Público, Lisboa, 14 jun. 2013. Ípsilon, p. 9.

RUBIM, Gustavo. Um texto estranho. Textos Pretextos, Lisboa, n. 17: Herberto Helder, p. 10-19, outono-inverno 2012.

SANTOS, Maria Irene Ramalho de Sousa - 'A cabeça entre as mãos', de Herberto Helder. Colóquio/Letras, Lisboa, n. 74, p. 74-75, jul. 1983. 
